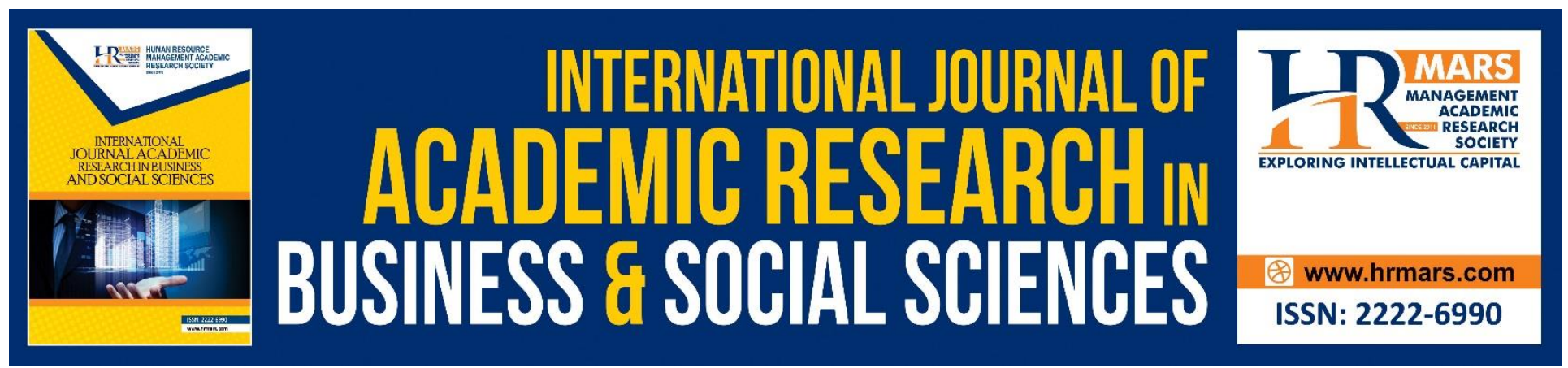

\title{
Mobile Library Attraction to Rural Community: A Proposed Framework
}

\author{
Nadiah Badrul Hisham and Che Zainab Abdullah
}

To Link this Article: http://dx.doi.org/10.6007/IJARBSS/v8-i9/4606

DOI: $\quad 10.6007 /$ IJARBSS/v8-i9/4606

Received: 03 August 2018, Revised: 22 September 2018, Accepted: 29 September 2018

Published Online: 15 October 2018

In-Text Citation: (Hisham \& Abdullah, 2018)

To Cite this Article: Hisham, N. B., \& Abdullah, C. Z. (2018). Mobile Library Attraction to Rural Community: A Proposed Framework. International Journal of Academic Research in Business and Social Sciences, 8(9), 476484.

Copyright: (C) 2018 The Author(s)

Published by Human Resource Management Academic Research Society (www.hrmars.com)

This article is published under the Creative Commons Attribution (CC BY 4.0) license. Anyone may reproduce, distribute, translate and create derivative works of this article (for both commercial and non-commercial purposes), subject to full attribution to the original publication and authors. The full terms of this license may be seen

at: http://creativecommons.org/licences/by/4.0/legalcode

Vol. 8, No. 9, September 2018, Pg. 476 - 484

http://hrmars.com/index.php/pages/detail/IJARBSS

JOURNAL HOMEPAGE

Full Terms \& Conditions of access and use can be found at http://hrmars.com/index.php/pages/detail/publication-ethics 


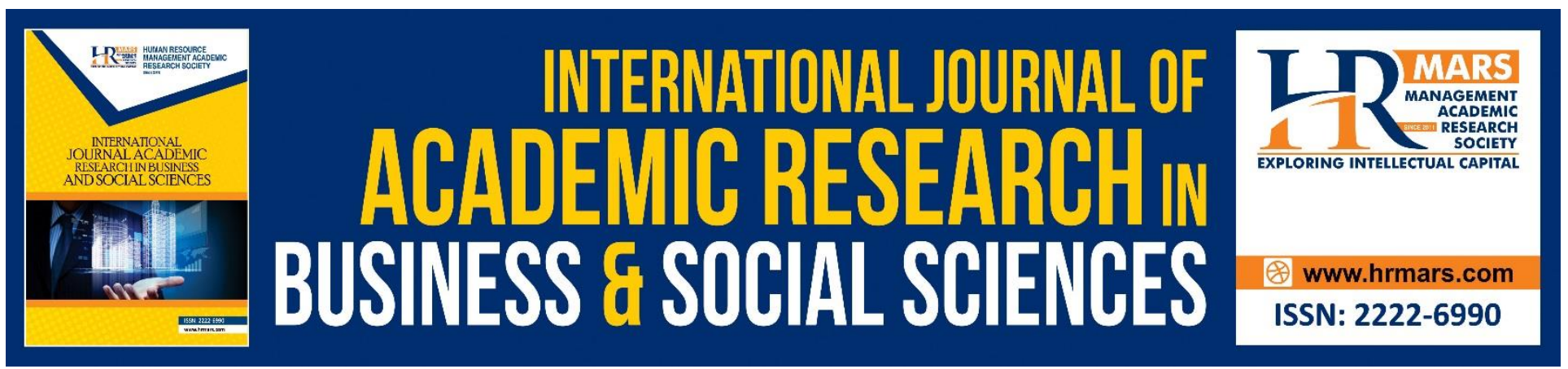

\title{
Mobile Library Attraction to Rural Community: A Proposed Framework
}

\author{
Nadiah Badrul Hisham and Che Zainab Abdullah
}

Faculty of Information Management, Universiti Teknologi MARA, UiTM Selangor, Malaysia.

\begin{abstract}
Mobile library is not new to many researchers it is considered very essential to rural community. To be effective and reliable of mobile library, it is essential for the library to offer better services that will bring intangible value to society. This concept paper aims to give an idea on how mobile library can attract user in the rural community by focusing on following aspects; outreach, accessibility and convenient with respect to the user satisfaction in rural community. Insight will benefited public library in served better to community.
\end{abstract}

Keywords: Mobile Library, Rural Community, Outreach, User Satisfaction

\section{INTRODUCTION}

In past years and new era, library not limited to the physical one only but also are wide and move to mobile library which is mobilize and can reach people far from town such as in rural areas. Mobile library can definite as devised, equipped and operated to provide, as far as reasonably practicable, a service comparable to a part-time branch library, (Library Association, 1960). Mobile libraries, by their nature, target their services to meet the needs of elderly and other less mobile people - those who may find it difficult to reach the nearest static libraries. Therefore decisions to provide mobile services in areas which have recently lost static libraries are affected by the presence of these vulnerable groups, which in turn requires a familiarity with the communities involved.

There are a number of varieties of mobile libraries to be found throughout the world. Bicycles, backpacks, boxes, boats, trains, streetcars, motorcycles, oxen, donkeys, elephants and camels are all different means to bring out books to remote areas. In Malaysia mobile library are using a bus and its started early in 1980. Mobile library are under public and state library in Malaysia. In the bid to serve children in the rural areas with the mobile library, the staff of the children's library stock the mobile library with books, journals, magazines and comics. Some audio visual materials may also be included, such as, films, maps, slides, projectors, tv monitors, DVDs and computers (laptops). When they get to these locations which maybe the village square or at times the village hall, children are made to line up to be served with these library resources. 
INTERNATIONAL JOURNAL OF ACADEMIC RESEARCH IN BUSINESS AND SOCIAL SCIENCES Vol. 8, No. 9, Sept. 2018, E-ISSN: 2222-6990 @ 2018 HRMARS

This paper will attempt to assess the value mobile library services to their catchment communities and focusing on following aspects; outreach, accessibility and convenient with respect to user satisfaction.

\section{LITERATURE REVIEW}

The Library Association Record (1960) gave the definition of the mobile library as "a vehicle devised, equipped and operated to provide as far as reasonably practicable, a service comparable to part-time branch library. Eastwood (1991) gave an improved definition of the mobile library as "a road vehicle especially equipped and furnished to provide a professional library service direct to the people.

\section{OUTREACH}

The activity of an organization in making contact and fostering relations with people unconnected with it, especially for the purpose of support or education and for increasing awareness of the organization's aims or message. In libraries, outreach is often described as services for those who are infrequent users or non-users, or as services for those who are traditionally underserved. Library outreach strives to provide equitable delivery of library services to all, through the development of programs, services and policies which make the library available to everyone - the ability to be in the community, to engage with community members and to offer specific targeted services. For many libraries, the motivation behind their outreach program is marketing as selling the library's services and programs to members of the community who do not or have not yet come into the library, for example pop-up libraries, which have the advantage of flexibility, low cost and adaptability, unlike static branches or mobile libraries.

Outreach services are generally services delivered externally to library members, the community and other stakeholder groups such as a school and can be a version of services, programs or other activities already being delivered at the physical branch such like a children's story time that cannot be delivered via current infrastructure for due to space constraints, or they may include programs specifically designed for individuals or groups that do not or cannot access the physical branch network. Pop-up services fit under this umbrella, as locations, scope and purpose will vary over time. Outreach programming or services are also an effective way of promoting the library to a wider community, and a way of reaching those who are either unable due to physical constraints to utilize physical services at a branch or who are not traditional library users. Outreach can also include the library going out into the community to 'bring people in', for example, new or disenfranchised groups.

\section{ACCESSIBILITY}

Accessibility in this study referred to the usability of a product, service, environment or facility by people with the widest range of capabilities. Library that people loved to visit must be accessible in term of user friendly and the resources are available to user to use it. Since their creation, and especially since the beginning of the Internet or information age, libraries have adapted to changes in technology. Since the Internet has rapidly changed the distribution channels worldwide, libraries and their vendors have evolved by offering an increasing number of services online. Additionally, as library users worldwide become accustomed to using the Internet as their primary source of information, they place demands on libraries as never before, further accelerating the need for a library that is available on demand at any convenient place (Kuntaliito, 2017). 
INTERNATIONAL JOURNAL OF ACADEMIC RESEARCH IN BUSINESS AND SOCIAL SCIENCES

Vol. 8, No. 9, Sept. 2018, E-ISSN: 2222-6990 @ 2018 HRMARS

Library resources that have a subscription model are not ideal because they lock valuable scholarly information behind a wall that can only be access by users with access to a costly subscription. Since many members of the public are not aware that scholarly information can be accessed through a library, they often are frustrated by the costs they are expected to pay in order to have access to walled content. Organizations are also utilizing repositories by digitizing their collections and making them available online. These collections do not require a user to by physically present in the library nor do they require any fees for access. Collections are varied and can include items such as digitized out of copyright books, historical newspapers, image and photo collections, and virtually any other resource that can be digitally scanned.

\section{CONVENIENT}

Convenient means suitable or agreeable to the needs or purpose; well-suited with respect to facility or ease in use; favorable, easy, or comfortable for use. Convenient encompasses more than the time it takes to fulfill an information need. There is research to suggest that convenient is more important to people than quick service. All libraries in the world must be convenient to the user because they provide services for them. Making user convenient means they provide best services to the community. Since the library is not the only game in town to get information and the majority of the population does not use libraries to get information (Connaway, 2013). It is important for the library to become embedded in the lifestyles of their users and potential users for those who may not or who seldom use library services. An overloaded information environment, many information users tend to experience a sense of information inadequacy and anxiety.

Insight into information seeking can be gained by understanding how users seek information sources and how they choose content to meet their needs. Yet the library and information science literature has neglected to study how individuals decide what and how much information is enough to meet their needs or goals. In today's fast-paced world, anecdotal evidence suggests that information tends to inundate people, and users of information systems want to find information quickly and conveniently. Convenient is a situational criterion in people's choices and actions during all stages of the information-seeking process. The concept of convenience can include their choice of an information source, their satisfaction and ease of use with the source, and their allocation of time for information seeking. The convenient in mobile library include Search engines are preferred they are faster and more convenient so easier to use, costeffective and reliable. A set of resources may be used consistently simply because that method is now predictable and familiar.

\section{USER SATISFACTION}

All libraries must include their service quality to know user satisfaction on services provided by the library. Zeithman and Bitmar (2000) defined users' satisfaction as the means which users determine that a product or service meet the required needs and expectations. If the products or services do not meet their needs or expectations, it is therefore assumed that they are dissatisfied with the product or services. Similarly, Iwhiwhu and Okorodudu (2012) stated that users satisfaction of library information resources and services is a way in which users judge the adequacy of the library information resources and services rendered to them and also if their expectations are provided to them. Library user satisfaction implies how users feel after using the information resources and services and their willingness to return to the library when next they need information (Ikenwe and Adegbilero-Iwari, 2014). According to ljiekhuamhen, Aghojare and Lerdinand (2015) the level of using 
INTERNATIONAL JOURNAL OF ACADEMIC RESEARCH IN BUSINESS AND SOCIAL SCIENCES

Vol. 8, No. 9, Sept. 2018, E-ISSN: 2222-6990 @ 2018 HRMARS

the library depends on users' satisfaction with the available information resources and services rendered to them.

In a nutshell, users' satisfaction could be considered as the satisfaction users derive from the library by using the various types of information resources and services to fulfil their information needs for their various daily activities. Thus, the availability of quality information resources and services in libraries do have a significant influence on users' satisfaction. When users are satisfied with library information resources, they not only come back but speak well of the library to other users.

\section{CONCEPTUAL FRAMEWORK}

Below is framework of this study that has been developed in this study. The independent variable in this study is outreach, economical, accessibility and convenience while for dependent variable is user satisfaction. The dimension use in this study is outreach, accessibility and convenience to find the relation with user satisfaction. The dimension in the framework is adapt from past studies which it have been done by other researchers to evaluate user satisfaction. User satisfaction is to measure how the services supplied by a library meet the community need. It focus on the importance of fulfilling user satisfaction in rural area.

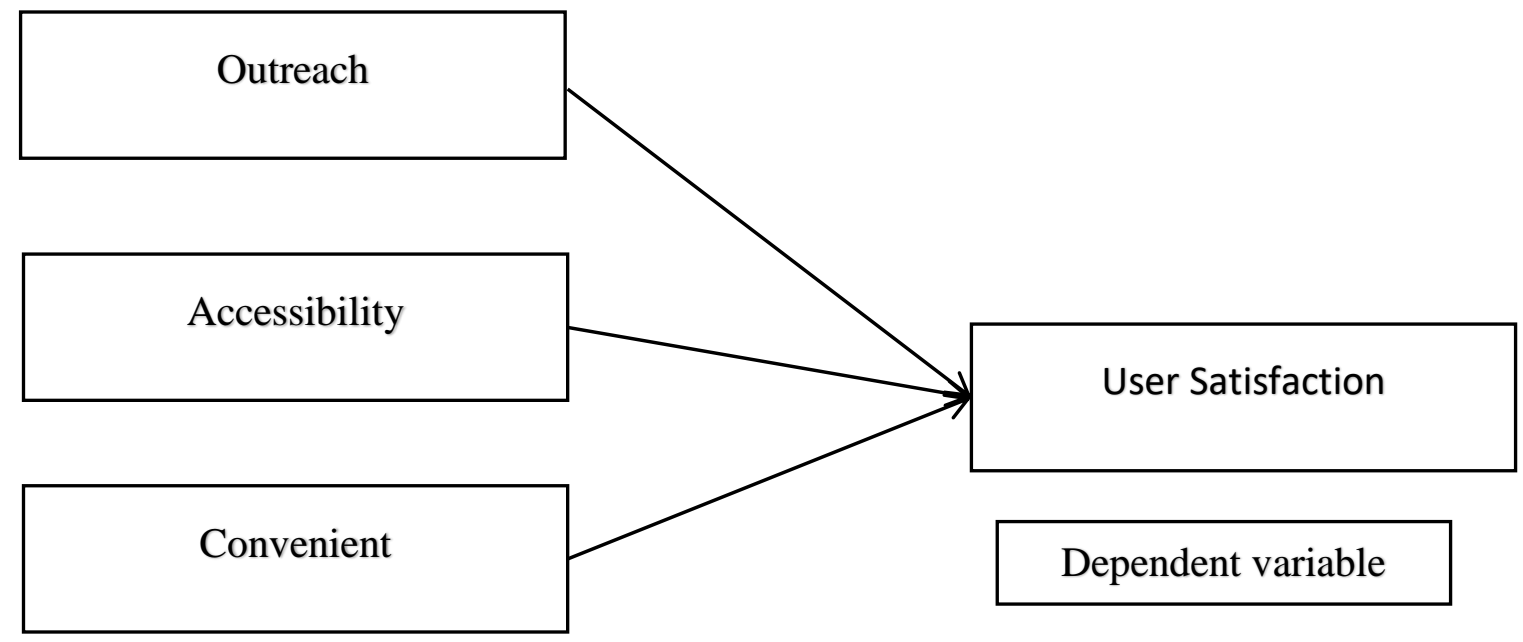

Independent variable 
INTERNATIONAL JOURNAL OF ACADEMIC RESEARCH IN BUSINESS AND SOCIAL SCIENCES Vol. 8, No. 9, Sept. 2018, E-ISSN: 2222-6990 @ 2018 HRMARS

\section{CONCLUSION}

Government should make conscious effort to develop rural areas. In effect, the people that live within rural communities not be denied with many social amenities. Because of this problem, many of them migrate to urban cities as a solution to their problem, while people who stay are denied from their social life. The most vital need of the rural populace is information which will help them to know their needs and how to satisfy them. So with mobile library, they can accessing information towards their hand and they can same like people in urban area, which get current and up to date information. Besides that, mobile libraries can create an atmosphere of informality. By stopping outside the houses of their users, mobile library assistants may get to know the main highly personalised light.

\section{REFERENCES}

Ahmad, P. (2005). Library services in distance educations systems: Guidelines and possibilities.

Ahmed, S. (2009). Fast internet becomes a legal right in Finland. CNN Online.

Retrieved from

http://www.cnn.com/2009/TECH/10/15/finland.internet.rights/index.htm

Ajibero, M.I. (2004). Donor support and sustainability: The experiences of university libraries.

Akanwa, P. C. (2013). Public Library Services to Children in Rural Areas. Library and Practice (eJournal).

American Library Association. (2009). Handbook for mobile services staff. http://www.ala.org/offices/sites/ala.org.offices/files/content/olos/bookmobiles/Mo bile_Services_Handbook.pdf [accessed August 2014]

Association of Bookmobiles and Outreach Services. (2004). Guidelines http://abos-outreach.org/resources/documents downloads/ [accessed August 2014]

Cassner, M. \& Adams, K. (2012). Continuing education for distance librarians. Journal of Library \& Information Services in Distance Learning, 6 (2), 117-128.

Connaway, L.S. (2015). The Library in the Life of the User: Engaging with People Where They Live and Learn. Dublin, Ohio: OCLC Research. http://www.oclc.org/content/dam/research/publications/2015/oclcresearch-library-in-lifeof-user.pdf

Connaway,L.S, Timothy J.D \& Marie L.R. (2011). If it is too inconvenient I'm not going after it:' Convenience as a critical factor in information-seeking behaviors. Library \& Information Science Research, 33 (3), 179-19.

Doust, R. W. Provision of School Library Services by Means of Mobile Libraries: The Zimbabwe Experience. IFLA Journal, 25 (3), 148-151. 
INTERNATIONAL JOURNAL OF ACADEMIC RESEARCH IN BUSINESS AND SOCIAL SCIENCES Vol. 8, No. 9, Sept. 2018, E-ISSN: 2222-6990 @ 2018 HRMARS

Eastwood, C.R. (1967). Mobile Libraries and other Public Library transport, association of Assistant Librarian, London.

General Economic Impact Libraries Matter. American Library Association, http://www.ala.org/tools/research/lilbrariesmatter/taxonomy/term/131 
INTERNATIONAL JOURNAL OF ACADEMIC RESEARCH IN BUSINESS AND SOCIAL SCIENCES

Vol. 8, No. 9, Sept. 2018, E-ISSN: 2222-6990 @ 2018 HRMARS

Glenn Davidson \& Dorner, D. (2009). Selection criteria for mobile library collections. Collection Building, 28 (2), 51-58.

Goodman, V.F.D. (2008). Rural library services: historical development and modern day examples from West Africa, New Library World, 109 (11/12).

Greenhalgh, L. \& Worpole, K. (1995). Libraries in a World of Cultural Change. London: U.C.L. Press.

Hunter, J. (1998). The Effectiveness of Mobile Library Provision in Urban Communities Which Have Lost Static Libraries: A Case Study.

Igben, M.J. (1993). Student's use of selected services in library. Nigeria Library Information Science Review, 2 (1), 6-17.

Jagell, K. (2003). Who does the mobile library reach: A minor field study of the bookmobiles of Bangkok, Thailand.

Kenneally, A. \& Payne, C. (2000). Mobile library services: Australian trends. APLIS, 13 (2), 63-71.

Kuntaliito, K. (2017). Accessibility Guidelines for public library.

Mabawonku, I. (2004). Library use in distance learning: a survey of undergraduates in three Nigerian University. African Journal of Library, Archives and Information Science, 14 (2), 151-165.

Motiang, I. P., Wallis, M \& Karodia, A. M. (2014). An evaluation of user satisfaction with library services at the University of Limpopo, Medunsa Campus (Medical University of Southern Africa). Arabian Journal of Business and Management Review, 3 (11), 41- 58.

Ogbuiyi, S. U., \& Okpe, I. J. (2013). Evaluation of library materials usage and services in private universities in Nigeria. Kuwait Chapter of Arabian Journal of Business and Management Review, 2 (8), 33-41. 
INTERNATIONAL JOURNAL OF ACADEMIC RESEARCH IN BUSINESS AND SOCIAL SCIENCES

Vol. 8, No. 9, Sept. 2018, E-ISSN: 2222-6990 (C) 2018 HRMARS

Oyelekan, G. O \& lyortsuun, J. A. (2011). An evaluative study of reader services in University of Agriculture library Makurdi. An international Journal of Information and Communication Technology (ICT), 8(2), 129-137.

Penny,W. (1990). The History and Development of Mobile Libraries. Library Management, 11 (2), 5-14.

Warrens, M.J. (2014). On Cronbach 's Alpha as the mean of all possible a split Alphas.

Worcester, R. (1981). Planning mobile library services in Essex. Service Point, 22, 4-7.

Wright, T. and Yuniar, Y. (2008). Poorer Nations Go Online on Cellphones. Wall Street Journal Eastern, 84.

Saika, M. \& Gohain, A. (2013). Use and user's satisfaction on library resources and services in Tezpur University (India): A study Library Philosophy and Practice.

Sakaran,U \& Bougie, R. (2010). Research method for business: A skill building approach, London: Wiley.

Zavar, T. (2004). Evaluating the quality of educational services to students in

Payamenoor Universities of the East and West Azerbaijan provinces. Journal

Research and Planning in Higher Education, 46 ,67-90.

Zeitman \& Bitmar. (2000). Definition of user satisfaction. McGraw Hill. 